\title{
Survival characteristics of pathogens inoculated into bottled mineral water
}

\author{
Rita Ramalho *, Anita Afonso, Joaquim Cunha, Paula Teixeira, Paul Anthony Gibbs \\ Escola Superior de Biotecnologia, Universidade Católica Portuguesa, Rua António Bernardino de Almeida, 4200-072 Porto, Portugal
}

Keywords: Pathogens; Mineral water; Hazard

\begin{abstract}
To assess the risk of contracting a waterborne disease from mineral water and to implement control systems in the mineral water industry, knowledge of the factors affecting the survival and multiplication of non-indigenous bacteria is needed. The survival of Escherichia coli, Salmonella typhimurium, Staphylococcus aureus and Yersinia enterocolitica inoculated into a Portuguese bottled mineral water was investigated under different conditions: light and dark, different recovery media, presence or absence of autochthonous flora and different ages of water, based on their culturability. For all the pathogenic bacteria higher survival was obtained under dark conditions of storage and when enumeration was performed on non-selective media. Survival of $E$. coli, $Y$. enterocolitica and $S$. typhimurium was longer in fresh water than in old water; results obtained with $S$. aureus were not conclusive. Survival of E. coli, $Y$. enterocolitica and $S$. typhimurium was lower in non-sterile mineral water while the survival of $S$. aureus was lower in sterilized mineral water. (C) 2001 Elsevier Science Ltd. All rights reserved.
\end{abstract}

\section{Introduction}

The microbiological quality of bottled mineral water is of great interest as many consumers use it as an alternative to mains water and consider it to be better and safer. Within the EU, the marketing of natural waters is governed by a Council Directive (Anonymous, 1980). According to this Directive, any treatment likely to change the viable colony count of the mineral water is not allolwed.

In addition to indigenous bacteria (autochthonous), considered to have no risk to public health, bottled mineral water may contain pathogenic contaminants. The most likely sources of contamination are equipment, bottles and caps, exposure to air and contact with humans during the bottling process (Warburton, Peterkin, Weiss, \& Johnston, 1986; Geldreich, 1989; Warburton \& Dodds, 1992; Defives, Guyard, Oularc, Mary, $\&$ Hornez, 1999) and contamination by the consumer. The occurrence of contamination will vary within countries and water industries. In some countries, for

\footnotetext{
${ }^{*}$ Corresponding author. Tel.: +351-225580045; fax: +351225090351.

E-mail address: rramalho@morango.esb.ucp.pt (R. Ramalho).
}

instance, it is allowed to have bottles of 51 of water which may increase the probability of contamination because bottles will stay opened for an extended time. The only welldocumented outbreak associated with bottled water occurred in Portugal in 1974 (Blake, Rosenberg, Florencia, Costa, \& Gangarosa, 1977) with Vibrio cholerae. Besides this outbreak, no other studies were able to identify any microbiological risk from drinking bottled waters but also none were able to show them to be free from such risk. Indeed, zero risk is not possible to exist.

The contaminant bacteria survive poorly in bottled water and may become physiologically injured with aquatic exposure because they are not well adapted to the chemical and physical conditions in water. In spite of unfavorable conditions, pathogens can remain viable in water and cause various gastric illnesses after being ingested (Hurst, 1977; McFeters, LeChevallier, Singh, \& Kippin, 1986; Barcina, Lebaron, \& Vives-Rego, 1997).

Information about survival/growth capacity of pathogenic bacteria in various waters stored under different conditions is crucial for the evaluation of possible risks and implementation of control systems such as hazard analysis and critical control point (HACCP) and to assist mineral water firms to supply safe products. It is also necessary to advice consumers about correct 
handling of bottled water. Concern about the use of Escherichia coli as an efficient indicator has been expressed since it was found that pathogenic bacteria such as Salmonella typhimurium persisted for at least 70 days in still mineral water while $E$. coli died after about 42 days (Hunter, 1993).

The current studies were designed to determine the ability of selected pathogens to survive in; a Portuguese bottled mineral water under light and dark conditions; with different ages after bottling; in the presence and absence of the autochthonous flora; and when using different recovery media (selective and non-selective).

\section{Materials and methods}

\subsection{Water samples}

The mineral water used was collected at a still mineral water bottling plant in Portugal. PET bottles $(0.331)$ containing natural mineral water and sterilized glass bottles (Schott; $100 \mathrm{ml})$ containing filtered $(0.2 \mu \mathrm{m}$ pore size Nuclepore filters) and heated $\left(60^{\circ} \mathrm{C} ; 20 \mathrm{~min}\right)$ mineral water (sterile water) were used (Colbourne, Trew, \& Dennis, 1988; Moreira, Agostinho, Vasconcellos Morais, \& da Costa, 1994).

The microbiological quality control of all mineral water was realized at the bottling plant; none of the pathogens used on this experiment was found in the mineral water.

\subsection{Pathogenic bacteria}

\subsubsection{Bacterial strains and growth conditions}

S. typhimurium 7738/32, Yersinia enterocolitica $\mathrm{Ger}$ 0:3 P-NS+ and E. coli NCTC 9001 were obtained from Leatherhead Food Research Association at Leatherhead, UK. Staphylococcus aureus NCTC 08532 was supplied by Centro de Qualidade of Escola Superior de Biotecnologia, Porto, Portugal.

A loop of all strains was inoculated into $20 \mathrm{ml}$ of Tryptic Soy Broth (Lab M) and incubated at $37^{\circ} \mathrm{C}$ for $S$. aureus, S. typhimurium and E. coli and at $21^{\circ} \mathrm{C}$ for $Y$. enterocolitica, for $24 \mathrm{~h}$. They were transferred to fresh TSB $(20 \mathrm{ml})$ at a final concentration of $1 \%(\mathrm{v} / \mathrm{v})$ and incubated as previously. Each culture was harvested by centrifugation $(3000 \times g$ for $10 \mathrm{~min})$ at ambient temperature, the supernatant fluid discarded, and the pellets resuspended in $20 \mathrm{ml}$ of sterile mineral water. This washing procedure was repeated three times with sterile mineral water before inoculation into mineral water in PET and glass bottles.

\subsubsection{Experimental conditions}

One $\mathrm{ml}$ of the final cell suspension was inoculated into PET bottles containing 0.331 of natural mineral water as supplied by the mineral water company and $300 \mu \mathrm{l}$ into sterilized glass bottles (Schott, Dural; Germany) containing $100 \mathrm{ml}$ of sterile mineral water and shaken vigorously to mix.

To study the effect of visible light on the survival of all pathogens, some inoculated bottles were stored under ambient light conditions while others were wrapped in aluminum foil to exclude light.

The effect of the autochthonous flora of the mineral water, on the survival of all the pathogens, was studied by comparing survival in the natural and sterilized mineral water. During earlier studies with $Y$. enterocolitica it was found that colonies of the pathogen were difficult to distinguish from those of the autochthonous flora on TSA and CIN. Therefore filtered and heated mineral water was used for the experiments with different recovery media.

Mineral water was also used immediately after bottling and approximately six months after bottling to study the influence of the age of water and levels of autochthonous organisms on the survival of the pathogens.

To look for an indication of injury selective and nonselective media were used. All the pathogens were enumerated on the non-selective medium Tryptic Soy Agar (Lab M; Bury, UK), colonies of the inoculated bacteria being readily distinguished from those of the autochthonous flora. The selective media used were Yersinia Selective Agar (CIN; Lab M) for Y. enterocolitica, xylose lysine decarboxylase (XLD) agar (XLD) (Lab M) and brilliant green agar (BGA) (Lab M) for $S$. typhimurium, violet red bile glucose agar (VRBGA) (Lab M) for $E$. coli and mannitol salt agar (MSA) (Lab M) and Baird-Parker agar (BPA) (Lab M) for S. aureus. $E$. coli was also enumerated on eosin methylene blue agar (EMB) (Lab M) (differential medium). Plates were incubated at $37^{\circ} \mathrm{C}$ for $24 \mathrm{~h}$, except $Y$. enterocolitica plates which were incubated at $21^{\circ} \mathrm{C}$. Plates inoculated with $S$. aureus were incubated for 24 and $48 \mathrm{~h}$.

All bottles and glass flasks were stored at $21^{\circ} \mathrm{C}$.

\subsubsection{Enumeration of survivors}

Bottles were sampled $(1 \mathrm{ml})$ one minute after the addition and mixing of the test strains and at regular intervals (following mixing by shaking) during storage. Decimal dilutions of the inoculated waters were made in maximum recovery diluent $(9 \mathrm{ml})(\mathrm{Lab} \mathrm{M})$ and $100 \mu \mathrm{l}$ samples were plated on the appropriate medium by the spread plate method.

Bacterial numbers were determined by counting the number of typical colonies on plates with $30-300$ colonies.

Data presented are mean values obtained from three independent experiments. The error bars on the figures indicate the mean standard deviations for the data points. 


\subsection{Autochthonous bacteria}

Decimal dilutions of the autochthonous flora present in natural (non-inoculated) mineral water in PET bottles were also made in maximum recovery diluent and $100 \mu \mathrm{l}$ samples were plated on R2A agar (Difco; USA) by the spread plate method.

Duplicate plates with 30-300 colonies were counted after 5 days of incubation at $37^{\circ} \mathrm{C}$ and after 21 days of incubation at $22^{\circ} \mathrm{C}$ under aerobic conditions, as suggested by Reasoner and Geldreich (1985) for the accurate study of the autochthonous flora since these microorganisms grow slowly.

\subsection{Statistical analysis}

Statistical analysis was done with the ANOVA methodology using Statview ${ }^{\mathrm{TM}}$ package (Abacus Concepts, Berkeley, CA) using as independent variable the starvation time. Bacterial counts were converted to $\log _{10}$ CFU per ml.

\section{Results and discussion}

High numbers of pathogens were used to obtain a survival/death curve over several logs without need for MPN or other laborious and, in some cases, with low reproducibility technique.

The viable counts of the bacteria decreased under both light and dark conditions, but the decrease depended on the microorganism and the conditions in which they were stored. The survival of the pathogens and of the autochthonous bacteria in mineral water was significantly higher $(P<0.0001)$ under dark conditions (Figs. 1 and 2, respectively). S. typhimurium presented the highest survival, followed by E. coli, Y. enterocolitica and $S$. aureus. These results support the earlier observation that both the UV and visible components of sunlight are lethal to bacteria. In fact, a range of potential phototoxic species are known to be produced

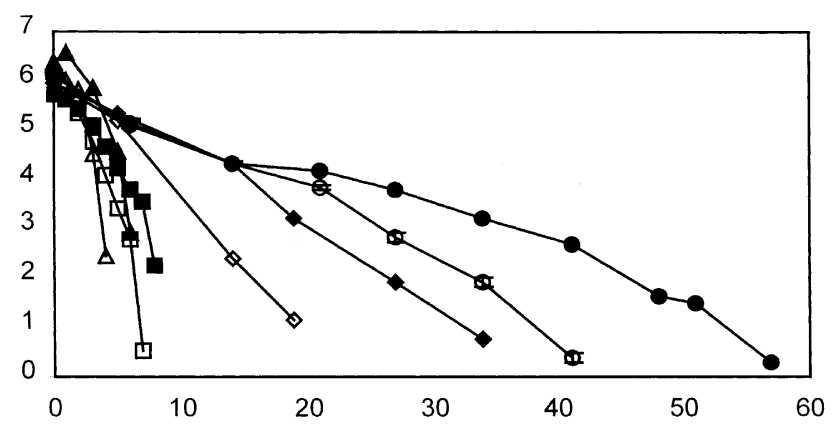

Fig. 1. Influence of light on the survival of the pathogens. Light: S. typhimurium $(\bigcirc)$ E. coli $(\diamond), Y$. enterocolitica $(\triangle)$, S. aureus $(\square)$; Dark: S. typhimurium $(\bullet)$ E. coli $(\diamond)$, Y. enterocolitica $(\boldsymbol{\Lambda})$, S. aureus $(\boldsymbol{\square})$.

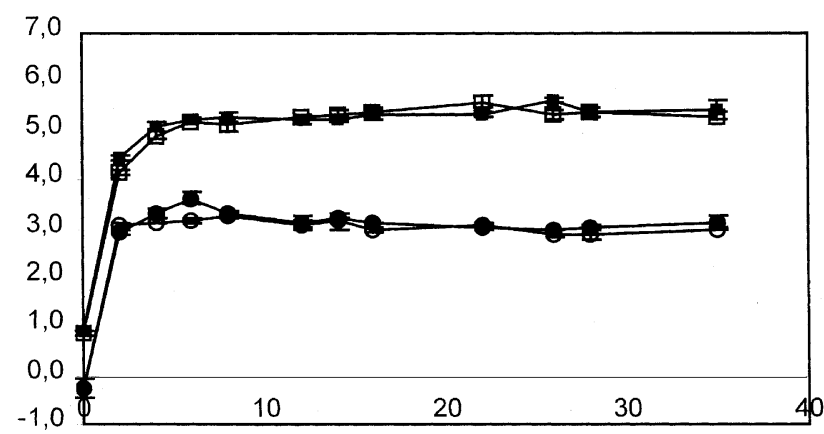

Fig. 2. Enumeration of the autochthonous flora stored under light and dark conditions. Light: $22^{\circ} \mathrm{C}(\square), 37^{\circ} \mathrm{C}(\bigcirc)$; Dark: $22^{\circ} \mathrm{C}(\boldsymbol{\square})$ $37^{\circ} \mathrm{C}(\bullet)$.

photochemically in natural waters, including peroxides, superoxide, hydroxyl radicals and singlet oxygen (Arana, Muela, Iriberri, Egea, \& Barcina, 1992; DaviesColley, Bell, \& Donnison, 1994; MacGregor et al., 1998). Since phototoxicity was correlated with illumination intensity (Gourmelon, Cillard, \& Pommepuy, 1994), all the following experiments were performed under dark conditions in order to avoid the possible interference of different intensities of light.

The bacteriological quality of bottled mineral water is determined, among other tests, by examining the presence/absence of indicator bacteria for faecal pollution such as E. coli. Indicators should be present in higher numbers than the pathogens and be more resistant to the aquatic environment, otherwise the absence of an indicator could not assure the absence of an enteric pathogen. Results showed that in this particular water, $S$. typhimurium presented the longest survival in both light and dark conditions, which may have serious implications for public health control analysis, since the absence of $E$. coli, used as an indicator organism, may not be proof that there is no contamination with $S$. $t y$ phimurium.

The pathogenic microorganisms were significantly better recovered on non-selective media than on their respective selective media $(P<0.0001)$ (Fig. 3)(a) and (b). These results support the earlier observation that one of the characteristics of injured microbes is loss of resistance to selective agents (Hurst, 1977; Barcina et al., 1997). The selective media probably have in their composition one or more ingredients to which starved cells of these pathogens are more sensitive, e.g. salt and sodium desoxycholate (Ray \& Johnson, 1984). A selection of colonies on TSA, typical of the inoculated pathogens, were confirmed by AP120NE (bioMerieux; Marcy l'Etoile, France) and Staphytec Plus (Oxoid; Hempshire); small colonies typical of the autochthonous flora, were ignored in the counts on TSA. Some authors have already shown that injured pathogens retain their ability to cause disease, therefore being capable of infecting humans if ingested in mineral water (Singh, Yeager, \& 


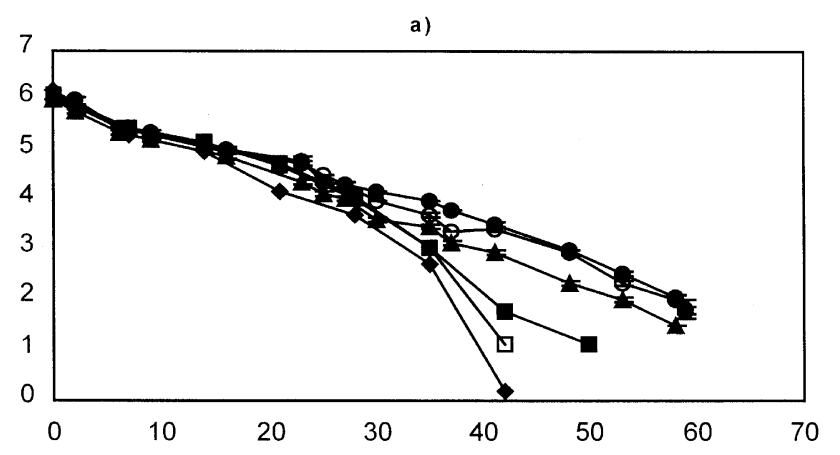

b)

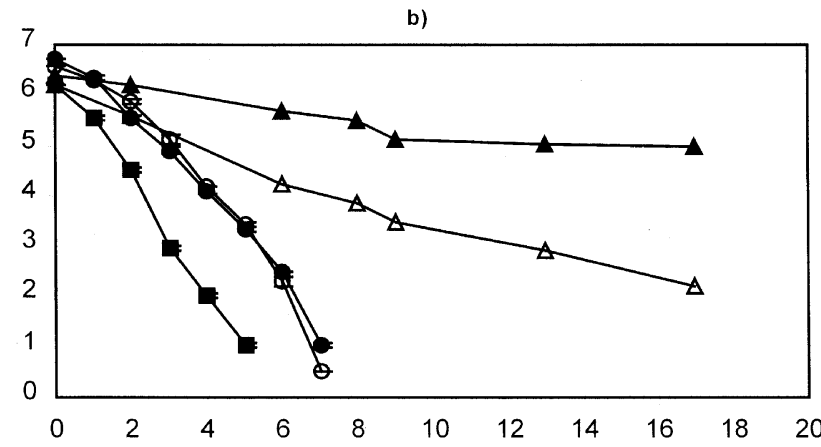

Fig. 3. Enumeration of different pathogens on selective and non-se-

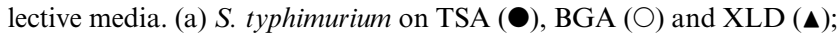
E. coli on TSA $(\bigcirc)$, EMB $(\square)$ and VRBGA $(\bullet)$. (b) S. aureus on TSA $(\bullet)$, BP $(\bigcirc)$ and MSA (ם) and Y. enterocolitica on TSA ( $\triangle)$ and CIN $(\triangle)$

McFeters, 1986; Singh \& McFeters, 1987; Walsh \& Bissonnette, 1987).

The age of water had different effects on the survival of the pathogens studied. The older the water the lower was the survival of $S$. typhimurium, E. coli and $Y$. enterocolitica (Fig. 4). Different and inconclusive results were obtained with $S$. aureus (data not shown). S. aureus survived better in the presence of the autochthonous flora, whereas S. typhimurium, E. coli and $Y$. enterocolitica were negatively influenced by their presence (Fig. 5).

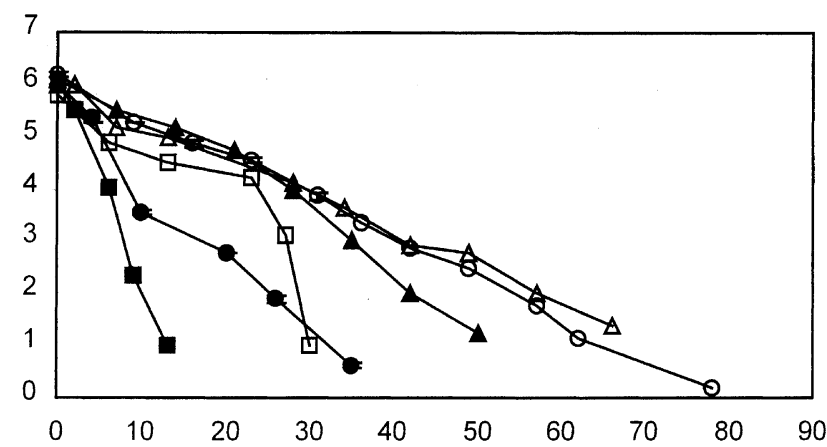

Fig. 4. Influence of the age of water on the survival of the pathogens. Fresh water: S. typhimurium $(\bigcirc)$, E. coli $(\triangle)$ and $Y$. enterocolitica $(\square)$; Old water: S. typhimurium $(\bullet)$, E.coli $(\mathbf{\Lambda})$, Y. enterocolitica $(\mathbf{\square})$.

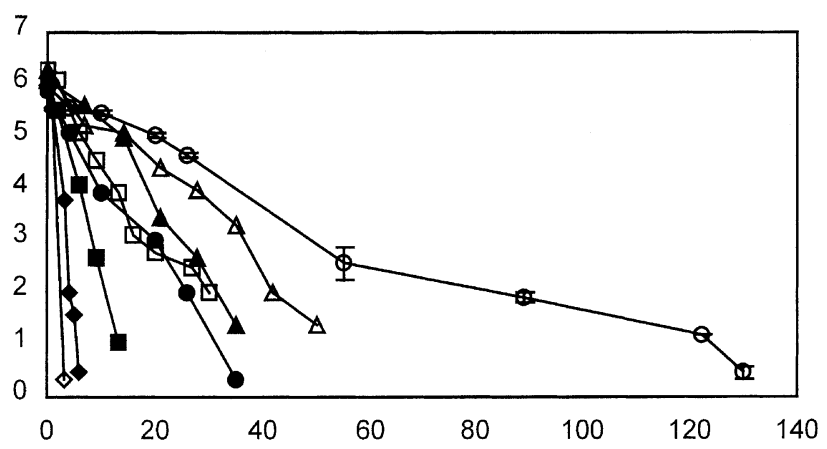

Fig. 5. Survival of pathogens in sterile and non-sterile mineral water. Sterile: S. typhimurium $(\bigcirc)$, E. coli $(\triangle)$, Y. enterocolitica $(\square), S$. aureus $(\diamond)$; Non-sterile: S. typhimurium $(\bullet)$, E. coli $(\boldsymbol{\Delta})$, Y. enterocolitica $(\mathbf{\square})$, S. aureus $(\diamond)$.

The autochthonous bacteria of mineral water have previously been reported to have an inhibitory effect on the survival of some indicator and pathogenic microorganisms (Ducluzeau, Nicolas, Galpin, \& Raibaud, 1984; Lim \& Flint, 1989; Lucas \& Ducluzeau, 1990; Korhonen \& Martikainen, 1991; Moreira, 1994; Kerr, Fitzgerald, Sheridan, McDowell, \& Blair, 1999). In the present study the autochthonous organisms had a negative effect on the survival of $S$. typhimurium, E. coli and $Y$. enterocolitica and a positive effect on the survival of S. aureus.

The effect of the autochthonous flora on the pathogens survival could be an explanation for the different survival obtained in sterile and non-sterile, fresh and old mineral water. As was reported previously (SchmidtLorenz, 1976; Gonzalez, Gutierrez, \& Grande, 1987; Bischofberger, Cha, Schmitt, Konig, \& Schmidt-Lorenz, 1990), in the first few days after bottling the number of autochthonous bacteria is relatively low $(\sim 10 \mathrm{cfu} / \mathrm{ml})$, increasing after approximatley three days of storage (to $10^{5}-10^{6} \mathrm{cfu} / \mathrm{ml}$ ), but remaining almost constant for the remainder of the storage period. Thus, in fresh water we have a low number of indigenous bacteria and consequently low quantities of any inhibitory substance that might be synthesized as a direct controlling action on the invader (Kersters et al., 1996), and also lower competition for the severely restricted nutrients (Lim \& Flint, 1989; Korhonen \& Martikainen, 1991). When the water was sterile, stable conditions were maintained during the rest of the experiment. Heating the water after filtration was necessary in order to obtain sterile water, since without that step, sterilisation could not be achieved due to the existence of autochthonous bacteria that could pass through $0.2 \mu \mathrm{m}$ pore size membrane filters (Jones, Chamberlain, \& Adams, 1999).

There was no significant difference between the recovery of the autochthonous flora from the uninoculated and from the inoculated water, which indicates that the presence of the pathogen had no apparent effect on the autochthonous flora (data not shown). 


\section{Conclusion}

This study demonstrates that, in general, the inoculated indicator and pathogenic bacteria show a progressive decrease in culturability in bottled mineral water, this decrease being accentuated in the presence of light. Depending on the microorganism being studied, the autochthonous flora generally had a negative effect on survival of pathogens. Pathogenic bacteria apparently become injured in mineral water which makes their accurate detection or enumeration unreliable on selective media. Given the serious consequences of falsenegative data in managing food safety, these results suggest that detailed research in the development of efficient methods for the recovery and analysis of important bacterial species is needed.

\section{Acknowledgements}

Financial support for authors Ramalho and Afonso was provided, respectively, by a Ph.D. and an M.Sc. fellowship issued by PRAXIS XXI (JNICT- BD/11496/ 97; JNICT-BM/6677/95) This work was financed by the EC FAIR project CT-961037- 'Improving methods and protocols used to insure the microbiological quality of bottled mineral water.' The authors acknowledge Sociedade das Águas de Luso, S.A.

\section{References}

Anonymous (1980). Directive du Conseil du Juillet 1980 relative au rapproachment des législation des Etats membres concernant l'exploitation et la mise dans le commerce des eaux minérales naturelles (80/777/CEE). Journal Officiel des Communautès Européennes, $\mathrm{N}^{\circ}$.L229/1-10.

Arana, I., Muela, A., Iriberri, J., Egea, L., \& Barcina, I. (1992). Role of hydrogen peroxide in loss of culturability mediated by visible light in Escherichia coli in a fresh water ecosystem. Applied and Environmental Microbiology, 58, 3903-3907.

Barcina, I., Lebaron, P., \& Vives-Rego, J. (1997). Survival of allochthonous bacteria in aquatic systems: a biological approach. FEMS Microbiol Ecology, 23, 1-9.

Bischofberger, T., Cha, S. K., Schmitt, R., Konig, B., \& SchmidtLorenz, W. (1990). The bacterial flora of non-carbonated natural mineral water from the springs to reservoir and glass and plastic bottles. International Journal of Food Microbiology, 11, 51-71.

Blake, P. A., Rosenberg, M. L., Florencia, J., Costa, J. B., \& Gangarosa, E. J. (1977). Cholera in Portugal, 1974. II. Transmission by bottled mineral water. American Journal of Epidemiology, 105, 344-348.

Colbourne, J. S., Trew, R. M., \& Dennis, P. J. (1988). Treatment of water for aquatic bacterial growth studies. Journal of Applied Bacteriology, 65, 79-85.

Davies-Colley, R. J., Bell, R. G., \& Donnison, A. M. (1994). Sunlight inactivation of Enterococci and faecal coliforms in sewage effluent diluted in seawater. Applied and Environmental Microbiology, 60, 2049-2058.

Defives, C., Guyard, S., Oularc, M. M., Mary, P., \& Hornez, J. P. (1999). Total counts culturable and viable and non-culturable microflora of a French mineral water a case study. Journal of Applied Microbiology, 86, 1033-1038.

Ducluzeau, R., Nicolas, J. L., Galpin, J. V., \& Raibaud, P. (1984). Influence of autochthonous bacteria on the longevity of Escherichia coli in bottled mineral water. Sciences des Aliments, 4, 585593

Geldreich, E. E. (1989). Drinking water microbiology - new directions toward water quality enhancement. International Journal of Food Microbiology, 9, 295-312.

Gonzalez, C., Gutierrez, C., \& Grande, T. (1987). Bacterial flora in bottled uncarbonated mineral drinking water. Canadian Journal of Microbiology, 33, 1120-1125.

Gourmelon, M., Cillard, J., \& Pommepuy, M. (1994). Visible light damage to Escherichia coli in seawater: oxidative stress hypothesis. Journal of Applied Bacteriology, 77, 105-112.

Hunter, P. R. (1993). The microbiology of bottled natural mineral waters. Journal of Applied Bacteriology, 74, 345-352.

Hurst, A. (1977). Bacterial injury: a review. Canadian Journal of Microbiology, 23, 936-944.

Jones, C. R., Chamberlain, A. H. L., \& Adams, M. R. (1999). An investigation of the presence of ultramicrocells in natural mineral water. Letters in Applied Microbiology, 28, 275-279.

Kerr, M., Fitzgerald, M., Sheridan, J. J., McDowell, D. A., \& Blair, I. S. (1999). Survival of Escherichia coli O157:H7 in bottled mineral water. Journal of Applied Microbiology, 87, 833-841.

Kersters, I., Huys, G., Van Duffel, H., Vancanney, M., Kersters, K., \& Verstraete, W. (1996). Survival potential of Aeromonas hydrophila in freshwaters and nutrient-poor waters in comparison with other bacteria. Journal of Applied Bacteriology, 80, 266-276.

Korhonen, L. K., \& Martikainen, P. J. (1991). Survival of Escherichia coli and Campylobacter jejuni in untreated and filtered lake water. Journal of Applied Bacteriology, 71, 379-382.

Lim, C. H., \& Flint, K. P. (1989). The effects of nutrients on the survival of Escherichia coli in lake water. Journal of Applied Bacteriology, 66, 559-569.

Lucas, F., \& Ducluzeau, R. (1990). Antagonistic role of various bacterial strains from the autochthonous flora of gas-free mineral water against Escherichia coli. Science des Aliments, 10, $65-73$.

MacGregor, S. J., Rowan, N. J., McIIvaney, L., Anderson, J. G., Fouracre, R. A., \& Farrish, O. (1998). Light inactivation of foodrelated pathogenic bacteria using a pulsed power source. Letters in Applied Microbiology, 27, 67-70.

McFeters, G. A., LeChevallier, M. W., Singh, A., \& Kippin, J. S. (1986). Health significance and occurence of injured bacteria in drinking water. Water Science Technology, 18, 227-231.

Moreira, L., Agostinho, P., Vasconcellos Morais, P., \& da Costa, M. S. (1994). Survival of allochthonous bacteria in still mineral water bottled in polyvinyl chloride (PVC) and glass. Journal of Applied Bacteriology, 77, 334-339.

Ray, B., \& Johnson, C. (1984). Survival and growth of freeze-stressed Campylobacter jejuni cells in selective media. Journal of Food Safety, 6, 183-195.

Reasoner, D. J., \& Geldreich, E. E. (1985). A new medium for the enumeration and subculture of bacteria from potable water. Applied and Environmental Microbiology, 49, 1-7.

Schmidt-Lorenz, W. (1976). Microbiological characteristics of natural mineral water. Annali Dell Instituto Superiore Di Sanita, 12, 93112

Singh, A., Yeager, R., \& McFeters, G. A. (1986). Assessment of in vivo revival, growth, and pathogenicity of Escherichia coli strains after copper and chlorine induced injury. Applied and Environmental Microbiology, 52, 832-837.

Singh, A., \& McFeters, G. A. (1987). Survival and virulence of copper and chlorine stressed Yersinia enterocolitica in experimentally infected mice. Applied and Environmental Microbiology, 53, 17681774 . 
Walsh, S. M., \& Bissonnette, G. K. (1987). Effect of chlorine injury on heat-labile exterotoxin production in enterotoxigenic Escherichia coli. Canadian Journal of Microbiology, 33, 1091-1096.

Warburton, D. W., Peterkin, P. I., Weiss, K. F., \& Johnston, M. A. (1986). Microbiological quality of bottled water sold in Canada. Canadian Journal of Epidemilogy, 105, 337-343.
Warburton, D. W., \& Dodds, K. L. (1992). A review of the microbiological quality of bottled water sold in Canada between 1981 and 1989. Canadian Journal of Microbiology, 38, 12-19. 